\title{
Study on two-stage air-recirculation ammonia stripping process for membrane concentrate in livestock and poultry breeding
}

\author{
Chen Junjie ${ }^{1}$, Zhu Hongguang ${ }^{1, *}$, and Ji jin ${ }^{1}$ \\ ${ }^{1}$ Bio-Energy Research Center, Institute of New Rural Development, Tongji University, Shanghai, 201804, China
}

\begin{abstract}
Aiming at the problems of the subsequent treatment of the biogas liquid membrane concentrate and the large alkali consumption of the traditional stripping process, a two-stage closed-cycle ammonia stripping process was designed, and the two-stage air-recirculation ammonia stripping process was used to treat the biogas liquid membrane concentrate. Studies have shown that in the first stage of ammonia stripping, when the gas-liquid ratio is 3600 , the $\mathrm{pH}$ of the membrane concentrate liquid after the closed loop treatment reaches the maximum value of 8.75 , and the alkalinity is also reduced from the initial 8150 to 6615.After the primary stripping is completed, the $\mathrm{pH}$ of the membrane concentrate can be quickly increased by adding alkali to meet the normal ammonia stripping conditions for the secondary stripping tower. When the liquid ratio of the secondary stripping tower is 3600 , the temperature is $40^{\circ} \mathrm{C}$, and the $\mathrm{CaO}$ dosage is $25 \mathrm{~g} / \mathrm{L}$, the removal rate of ammonia nitrogen is $86 \%$. Adding a first-stage tower blowing off, the $\mathrm{CaO}$ dosage is reduced by $5 \mathrm{~g} / \mathrm{L}$.
\end{abstract}

\section{Introduction}

In recent years, biogas projects have been widely used for the treatment of large-scale livestock and poultry farming manures, but at the same time, wastes such as biogas residues and liquids will also be generated. Biogas liquids can be used as good fertilizers for subsequent use. Due to the basic national conditions of Separation of planting and breeding, the biogas slurry in most farms cannot be effectively returned to the field. The biogas slurry membrane concentration technology has both separation and concentration methods, and is energy-saving, efficient and environmentally friendly. At present, there have been a lot of researches on biogas slurry nanofiltration, ultrafiltration and reverse osmosis [1-3]. Membrane concentration can remove COD well, but it cannot remove ammonia nitrogen efficiently.

For nitrogen reduction and recovery methods, mainly including physical methods, chemical methods, biological methods, etc. Among them, physical methods include reverse osmosis, distillation and other technologies; chemical methods include ion exchange, ammonia stripping, breaking point chlorination, incineration, catalytic cracking, electrodialysis, electrochemical treatment and other technologies; biological methods include algae cultivation, biological nitrification, and denitrification.[4]. The stripping method is the most commonly used physical method to treat ammonia nitrogen wastewater. It uses the difference between the concentration of volatile substances such as ammonia nitrogen contained in the wastewater and the corresponding equilibrium concentration in the gas phase. Under alkaline conditions, it is stripped with air or steam.
Stripping makes the ammonia nitrogen and other volatile substances in the wastewater continuously transfer from the liquid phase to the gas phase, so as to achieve the purpose of removing ammonia nitrogen from the wastewater [5].

The stripping method has been studied in different fields due to its high ammonia nitrogen removal rate, low treatment cost, simple equipment system, etc. It has been widely used as the treatment of ammonia nitrogen wastewater such as landfill leachate, coking wastewater, livestock and poultry breeding wastewater,[6-10] Compared with other physical and chemical treatment methods, the stripping method does not require complicated equipment, has simple process, simple operation and relatively low operating cost, and is an efficient physical and chemical denitrification process. The main factors affecting ammonia stripping are airliquid ratio, $\mathrm{pH}$ value, stripping time, temperature.[7]. Although the stripping method can effectively remove ammonia nitrogen, it consumes a large amount of alkali, and the stripping tower is prone to problems such as scaling and wall flow. Aiming at the above problems, this paper proposes a two-stage closed-cycle ammonia stripping system to study the effect of the system on the treatment of ammonia nitrogen in the liquid membrane concentrate of livestock and poultry breeding, and provide technical reference for the subsequent use of the process and the advanced treatment of the biogas slurry.

\section{Experimental materials, devices and methods}

\footnotetext{
* Corresponding author: zhuhg@tongji.edu.cn
} 


\subsection{Experimental materials}

The biogas slurry used in the experiment was taken from the anaerobic digestion liquid from a large-scale pig farm in Jiading District, Shanghai, which was concentrated and separated by ultrafiltration membrane. The test water quality indicators are shown in Table 1.

Table 1. Water quality index of biogas slurry in ammonia stripping experiment

\begin{tabular}{cccccc}
\hline Index & $\begin{array}{c}\mathrm{pH} \\
\text { value }\end{array}$ & $\begin{array}{c}\text { Alkalinity } \\
\left(\mathrm{mg} \cdot \mathrm{L}^{-1}\right)\end{array}$ & $\begin{array}{c}\mathrm{COD} \\
\left(\mathrm{mg} \cdot \mathrm{L}^{-1}\right)\end{array}$ & $\begin{array}{c}\mathrm{NH}_{4}{ }^{+}-\mathrm{N} \\
\left(\mathrm{mg} \cdot \mathrm{L}^{-1}\right)\end{array}$ & $\begin{array}{c}\mathrm{TP} \\
\left(\mathrm{mg} \cdot \mathrm{L}^{-1}\right)\end{array}$ \\
\hline $\begin{array}{c}\text { Biogas } \\
\text { slurry }\end{array}$ & 7.8 & 8150 & $4000 \sim 5000$ & $600 \sim 700$ & $100 \sim 120$ \\
\hline
\end{tabular}

\subsection{Experimental device}

The two-stage closed air-circulation system consists of a first-stage stripping tower, a second-stage stripping tower, a strong acid absorption tower and a strong alkali absorption tower. The material of the stripping tower is made of organic glass resistant to acid and alkali corrosion. The tower is $1.2 \mathrm{~m}$ long and $100 \mathrm{~mm}$ in diameter. The top of the tower is equipped with a spray head, the tower body is equipped with an exhaust port, the tower body and the liquid storage tank are sealed with flanges, the liquid collection tank adopts a cylindrical structure, a pressure relief valve is installed on the top, and a heater is installed inside. The packing layer adopts polyethylene hollow polyhedral sphere with a diameter of $25 \mathrm{~mm}$, the height of the packing layer is $1 \mathrm{~m}$. The $\mathrm{CO}_{2}$ absorber and ammonia absorber are also made of plexiglass, the size is $20 \mathrm{~cm} \times 20 \mathrm{~cm} \times 30 \mathrm{~cm}$, and the cylindrical structure is still adopted. The inlet of the intake pipe is about $5 \mathrm{~cm}$ away from the bottom of the reactor, and the top of the ammonia absorber is reversely installed to relieve pressure valve.

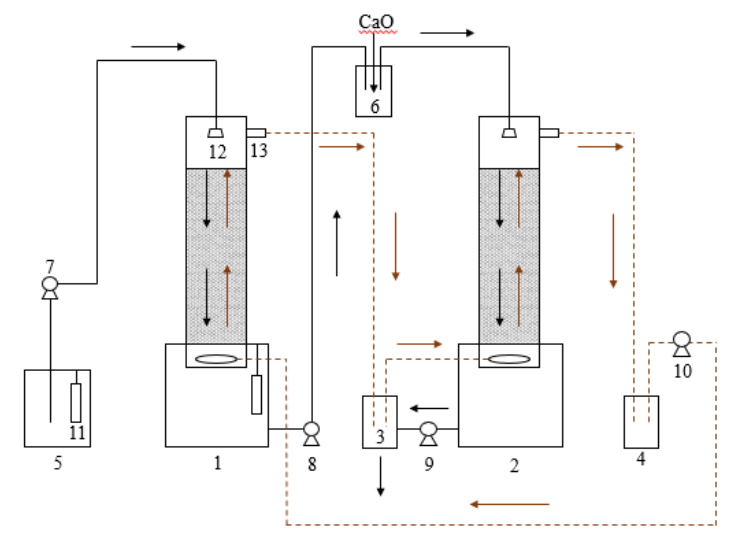

Fig. 1. Schematic diagram of two-stage air-recirculated stripping system.(1) First stage stripping tower; (2) Second stage stripping tower; (3) $\mathrm{CO}_{2}$ absorber tank; (4) $\mathrm{NH}_{3}$ absorber tank; (5) Liquid storage tank; (6) Mixing tank; (7) Biogas

slurry peristaltic pump $1 ;(8)$ Biogas slurry peristaltic pump 2;

(9) Biogas slurry peristaltic pump 3; (10) Air pump; (11) Heating rod; (12) Sprinkler; (13) Gas outlet
At the beginning of the experiment, the air is circulated according to the following process, the air is sprayed from the aeration port at the bottom of the first-stage stripping tower, flows from bottom to top, and then enters the $\mathrm{CO}_{2}$ absorber from the air outlet to remove $\mathrm{CO}_{2}$. Then follow the pipeline to the bottom of the secondary stripping tower, flow through the packing layer, and finally enter the ammonia absorber from the air outlet. After removing the ammonia from the gas, it will be sent back to the primary stripping tower by the air pump to form a closed loop system. At the beginning of stripping, the biogas slurry is pumped into the top of the first-stage tower through the liquid inlet tank, flows down through the top nozzle, and enters the liquid storage tank at the bottom of the stripping tower, and then is extracted by the peristaltic pump and sent to the agitator. Add alkaline agent to adjust the $\mathrm{pH}$ of the solution to 11 , and then send it to the top of the secondary tower by a water pump, and flow down through the nozzle. After reaching the bottom of the tower, it is sent to the $\mathrm{CO}_{2}$ absorber through a pipe.After absorbing the $\mathrm{CO}_{2}$ in the exhaust gas from the first-stage tower, it is discharged out of the system.

\subsubsection{Effects of temperature on the first stage stripping}

There are various forms of carbonic acid compounds in livestock wastewater and effluent after anaerobic digestion, these carbonates are important factors in determining the $\mathrm{pH}$ value of these water quality systems, and make the water quality systems have buffer capacity for external acid and alkali.Carbonic acid mainly exists in four forms of $\mathrm{CO}_{2}, \mathrm{H}_{2} \mathrm{CO}_{3}, \mathrm{HCO}_{3}{ }^{-}$and $\mathrm{CO}_{3}{ }^{2-}$ [11]. In the process of stripping and aeration, the free $\mathrm{CO}_{2}$ will be blown out first due to the low solubility of $\mathrm{CO}_{2}$. When the concentration of dissolved $\mathrm{CO}_{2}$ gradually decreases, The $\mathrm{HCO}_{3}{ }^{-}$and $\mathrm{H}^{+}$in the anaerobic digestion solution have the following ionization equilibrium formula:

$$
\mathrm{HCO}_{3}{ }^{-}+\mathrm{H}^{+}=\mathrm{CO}_{2}+\mathrm{H}_{2} \mathrm{O}
$$

The relationship between $\mathrm{HCO}_{3}{ }^{-}$and $\mathrm{CO}_{2}$ can be drawn:

$$
\left[\mathrm{HCO}_{3}^{-}\right]=\left[\mathrm{CO}_{2}\right] \times \mathrm{K}_{1} /\left[\mathrm{H}^{+}\right]
$$

The ionization constant $\mathrm{K}_{1}$ is a fixed value. When the anaerobic digestion solution is stripping, the dissolved $\mathrm{CO}_{2}$ concentration will continue to decrease, the equilibrium system will shift, and the $\mathrm{HCO}_{3}{ }^{-}$and hydrogen ions in the water will also continue to decrease.According to the equilibrium relationship of water ionization, $\mathrm{OH}^{-}$ions continue to increase, and the $\mathrm{pH}$ value of the solution rises accordingly. Kim [12] et al. used the stripping process to remove $\mathrm{CO}_{2}$ from the solution and increase the $\mathrm{pH}$ value of the anaerobic digestion solution of the sludge bed of the paper mill, so that the alkalinity of the anaerobic digestion solution was precipitated in the form of calcium carbonate. Therefore, the pretreatment by stripping can reduce the alkalinity of

\subsection{Experimental method}


the anaerobic digestion solution, increase the $\mathrm{pH}$, and reduce the amount of alkaline substances added in the ammonia stripping, which is beneficial in terms of economic costs and environmental ecology.

This experiment first explores the pretreatment effect of the first stage stripping tower on membrane concentration. The experimental device is shown in the Figure 2.

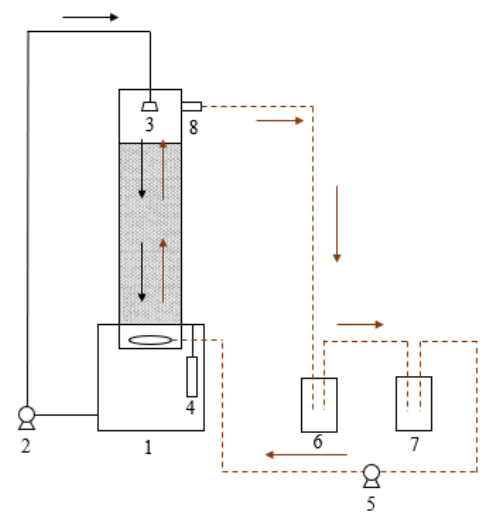

Fig.2 Schematic diagram of first stage air-recirculated stripping system. (1) Stripping tower; (2) Biogas slurry peristaltic pump (3) Sprinkler; (4) Heating rod; (5).Air pump (6) $\mathrm{CO}_{2}$ absorber tank (7) $\mathrm{NH}_{3}$ absorber tank; (8) Gas outlet;

Turn on the regulating valve switch, the system is in an open state, set three temperature gradients of 20,30, and $40^{\circ} \mathrm{C}$, adjust the flow rate of the diaphragm vacuum pump to $60 \mathrm{~L} / \mathrm{min}$, and use a heating rod to heat 3 parts of $1 \mathrm{~L}$ anaerobic digestion solution to $20,30,40{ }^{\circ} \mathrm{C}$ and then perform ammonia stripping, take samples from the liquid outlet according to different gas-liquid ratios to determine the ammonia nitrogen concentration, $\mathrm{pH}$ and alkalinity, and conduct three parallel tests. The optimum temperature of ammonia stripping was analyzed by the change curves of ammonia concentration, $\mathrm{PH}$ and alkalinity.

\subsubsection{Effects of system status on the first-stage stripping}

Turn off the regulating valve switch, and the system is in a closed loop state. According to the optimum temperature obtained before, set the diaphragm vacuum pump flow rate to $60 \mathrm{~L} / \mathrm{min}$, and use a heating rod to heat $1 \mathrm{~L}$ anaerobic digestion to the optimum temperature.The $\mathrm{pH}$ value and alkalinity of the anaerobic digestion solution are measured.

\subsubsection{Effects of different doses of alkaline agent on the $\mathrm{PH}$ of the effluent from the first-stage tower}

Take 3 parts of $1 \mathrm{~L}$ effluent of first-stage tower and untreated membrane concentrate, and add 15, 20, 25g/L $\mathrm{CaO}$ respectively, and measure the variation of $\mathrm{pH}$ value after stirring and precipitation.

\subsubsection{Treatment effect of the secondary tower on the effluent that has been added with alkali}

When the dosage of $\mathrm{CaO}$ is $15 \mathrm{~g}, 20 \mathrm{~g}, 25 \mathrm{~g} / \mathrm{L}$, the effect of the second-stage stripping on the removal of ammonia nitrogen and COD.

\subsubsection{Test methods}

Turn off the control valve switch to make the stripping system in a closed loop state, according to the optimum temperature obtained before, set the diaphragm vacuum pump flow rate to $60 \mathrm{~L} / \mathrm{min}$, and use a heating rod to heat $1 \mathrm{~L}$ anaerobic digestion liquid After reaching the most suitable temperature, blow off and measure the $\mathrm{pH}$ and alkalinity of the anaerobic digestion solution.

\section{Experimental results and analysis}

\subsection{Effects of temperature on first-stage stripping}

Variations of $\mathrm{pH}$ with air-liquid ratio and alkalinity at different temperatures are shown in Figure 3 and Figure 4. At the beginning of the experiment, due to the low $\mathrm{pH}$ and the greater alkalinity of the membrane concentrate, the increase in $\mathrm{pH}$ and the decrease in alkalinity have significant effects. As the air-liquid ratio increases, the curves of $\mathrm{pH}$ and alkalinity tend to stable. It is found from the figure that when the $\mathrm{pH}$ is greater than 8.3 , the rate of change of the $\mathrm{pH}$ curve slows down, and the effect of the change of air-liquid ratio on the $\mathrm{pH}$ in the anaerobic digestion solution is significantly reduced, but the alkalinity curve does not change significantly after the $\mathrm{pH}$ exceeds 8.3. It may be because the alkalinity is mainly dominated by the first-order carbonic acid ionization balance, and the $\mathrm{pH}$ value of the anaerobic digestion liquid is the result of the combined effect of the air-liquid carbon dioxide balance, the acid-base balance in the liquid phase, and the dissolution balance between the solid and liquid phases. [13], making the buffering capacity of the solution strong. When the temperature is $20^{\circ} \mathrm{C}$, whether it is $\mathrm{pH}$ or alkalinity, the range of change is much lower than the range of change under the other two temperature conditions. This is because the solubility of $\mathrm{CO}_{2}$ will decrease as the temperature rises. The best temperature is above $20^{\circ} \mathrm{C}$. When the air-liquid ratio was 3600 , the $\mathrm{pH}$ of the treatment solution at $40^{\circ}$ $\mathrm{C}$ increased from 7.8 to 8.63 , and the alkalinity also decreased from the initial 8150 to 6745 .

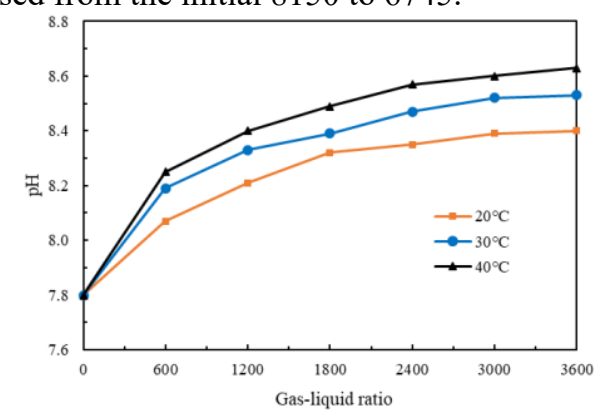

Fig. 3. Variations of $\mathrm{pH}$ with gas-liquid ratio at different temperatures 


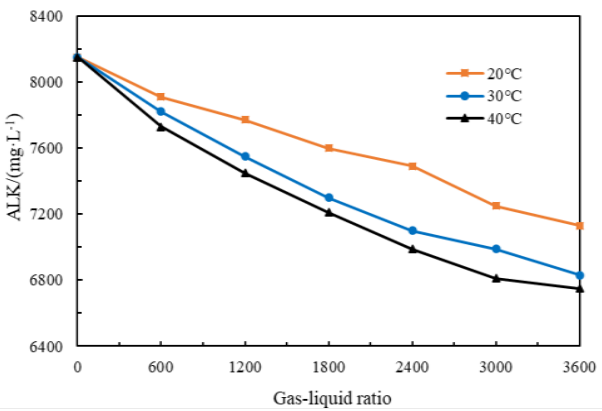

Fig. 4. Variations of alkalinity with gas-liquid ratio at different temperatures

Figure 5 shows the concentration change curve of ammonia nitrogen in the anaerobic digestion solution at different temperatures after the primary stripping treatment. In the absence of an alkali agent, the air-liquid ratio and temperature become the main factors affecting the removal of ammonia nitrogen. The ammonia nitrogen concentration keeps decreasing as the temperature rises and the air-liquid ratio increases. When the air-liquid ratio was 3600 , the concentration of the anaerobic digestion solution under the three temperature conditions dropped from the original $671 \mathrm{mg} / \mathrm{L}$ to 656 , 636 , and $592 \mathrm{mg} / \mathrm{L}$, and the removal rates were $2.2 \%$, $5.2 \%$ and $11.8 \%$.

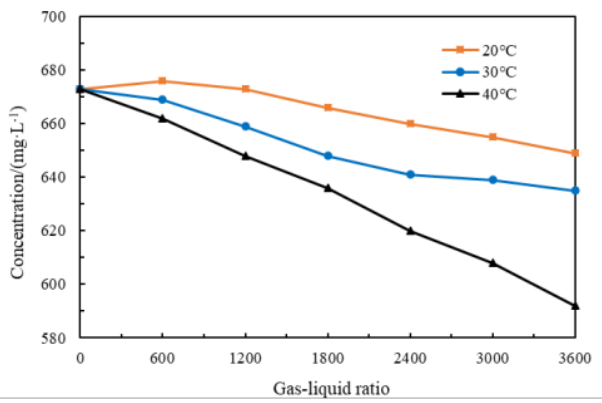

Fig. 5. Variations of ammonia nitrogen concentration with gasliquid ratio at different temperatures

\subsection{Effects of the state of the experimental device on the first-stage stripping}

The content of $\mathrm{CO}_{2}$ in the air is about $0.038 \%$. Reducing the content of $\mathrm{CO}_{2}$ can increase the partial pressure difference between the gas phase and the liquid phase of $\mathrm{CO}_{2}$, and increase the mass transfer driving force of the free $\mathrm{CO}_{2}$ in the solution to the gas phase.Thereby improving the stripping effect of the first stage tower[14].Figure 6 and 7 respectively show the treatment effects of the closed loop system on the $\mathrm{pH}$ and alkalinity in the anaerobic digestion solution. As the gasliquid ratio increases, the closed loop system raises the membrane concentrate $\mathrm{pH}$ faster than the open loop system, and the gap between the two is increasing. When the gas-liquid ratio is 3600 , the $\mathrm{pH}$ of the solution treated by the closed loop system reached 8.75 , and the $\mathrm{pH}$ of the solution treated by the open loop system is 8.63.The alkalinity change range of the membrane concentrate treated by the closed loop system is also significantly greater than the alkalinity change range of the concentrated liquid processed by the open system. When the gas-liquid ratio is 3600 , The alkalinity of the closed loop system decreased from the initial $8150 \mathrm{mg} / \mathrm{L}$ to $6615 \mathrm{mg} / \mathrm{L}$, and the alkalinity of the open loop system decreased from the initial $8150 \mathrm{mg} / \mathrm{L}$ to $6745 \mathrm{mg} / \mathrm{L}$.

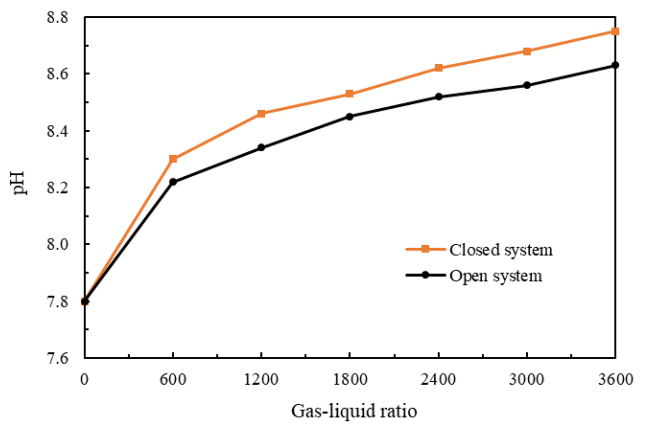

Fig. 6. Effects of system state on $\mathrm{pH}$ of Membrane concentrate

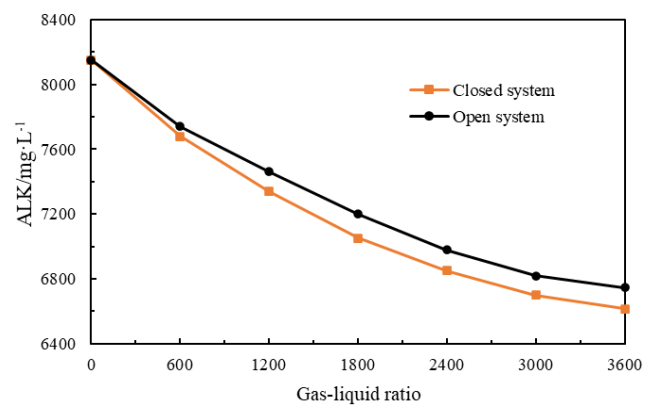

Fig. 7. Effects of system state on alkalinity of Membrane concentrate

\subsection{Effect of different dosages of calcium oxide on the effluent of the first stage tower}

According to the above experimental results, and considering the experimental effect and economy, the temperature of $40^{\circ} \mathrm{C}$ is selected as the experimental temperature, and the gas-liquid ratio is 3600 for the experiment. The effluent of the first-stage tower is taken as the test water sample, and different dosages of alkali are added to the effluent. The $\mathrm{pH}$ change of the water was investigated, and the test was carried out in the untreated concentrated liquid at the same time as a parallel test. The test results are shown in Figure 8. When the dosage of the alkali agent was $8 \mathrm{~g}$, the $\mathrm{pH}$ of the effluent increased by 0.44 to 9.01 , and the $\mathrm{pH}$ of the untreated membrane concentrate increased by 0.46 to 8.26 .

When the dosage of $\mathrm{CaO}$ is greater than $10 \mathrm{~g} / \mathrm{L}$, the two $\mathrm{pH}$ curves increase significantly. This may be because $\mathrm{CaO}$ has removed most of the alkalinity at this time, and the buffering capacity of the treatment solution is weakened, so the $\mathrm{pH}$ increase rate becomes faster.Similarly, when the $\mathrm{pH}$ of the solution is raised to 9 , the membrane concentrate treated by the first-stage tower needs to consume $8 \mathrm{~g}$ of $\mathrm{CaO}$, and the untreated membrane concentrate needs to consume $12 \mathrm{~g} / \mathrm{L}$. When the $\mathrm{pH}$ is raised to 10.5 , the membrane concentrate treated by the first-stage tower needs to consume $15 \mathrm{~g} / \mathrm{L}$ of $\mathrm{CaO}$, and the untreated membrane concentrate needs 
to consume $20 \mathrm{~g} / \mathrm{L}$. Therefore, when adding $\mathrm{CaO}$ as a means to increase the $\mathrm{pH}$ of the solution, the mass of $\mathrm{CaO}$ required for the membrane concentrate after the primary tower stripping treatment is about $25 \%$ lower than that of the untreated membrane concentrate.

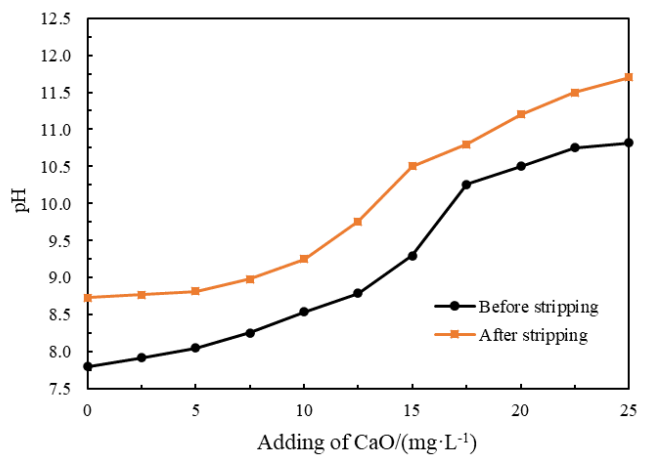

Fig. 8. Effects of the dosage of calcium Oxide added on the $\mathrm{pH}$ of the effluent of the first stage tower

\subsection{Effect of second-stage stripping on ammonia nitrogen in effluent}

Figure 9 shows the removal rate curve of ammonia nitrogen in the effluent from the secondary stripping tower when the $\mathrm{CaO}$ addition amount is $15 \mathrm{~g}, 20 \mathrm{~g}, 25 \mathrm{~g}$. When the gas-liquid ratio of the secondary tower is 600 , and the amount of $\mathrm{CaO}$ added to the inlet water is $25 \mathrm{~g} / \mathrm{L}$, the ammonia nitrogen content in the effluent from the se condary tower is $250.5 \mathrm{mg} / \mathrm{L}$, and the removal rate is 6 $0 \%$. When the amount of $\mathrm{CaO}$ added to the influent water is $20 \mathrm{~g} / \mathrm{L}$, the ammonia nitrogen content of the effluent is $262.92 \mathrm{mg} / \mathrm{L}$ and the removal rate is $58 \%$. When the amo unt of $\mathrm{CaO}$ added is $15 \mathrm{~g}$, the ammonia nitrogen content $\mathrm{i}$ $\mathrm{s} 281.7 \mathrm{mg} / \mathrm{L}$ and the removal rate is $55 \%$. . When the gas -liquid ratio is 2400 , the growth rate of ammonia nitroge $\mathrm{n}$ removal slows down. When the $\mathrm{CaO}$ dosage is $15 \mathrm{~g} / \mathrm{L}$, $20 \mathrm{~g} / \mathrm{L}, 25 \mathrm{~g} / \mathrm{L}$, the ammonia nitrogen content is $150 \mathrm{mg} / \mathrm{L}$, $138.7 \mathrm{mg} / \mathrm{L}, 137.72 \mathrm{mg}$, respectively $/ \mathrm{L}$, the removal rat e is $76 \%, 77 \%, 78 \%$. When the gas-liquid ratio is $3600, \mathrm{t}$ he maximum ammonia nitrogen removal rate correspond ing to the dosage of the three calcium agents is $83.1 \%, 8$ $5 \%$, and $86 \%$ respectively. At this time, the ammonia nit rogen content of the secondary tower effluent is $105 \mathrm{mg}$ / $\mathrm{L}, 93.9 \mathrm{mg} / \mathrm{L}, 87.6 \mathrm{mg} / \mathrm{L}$.

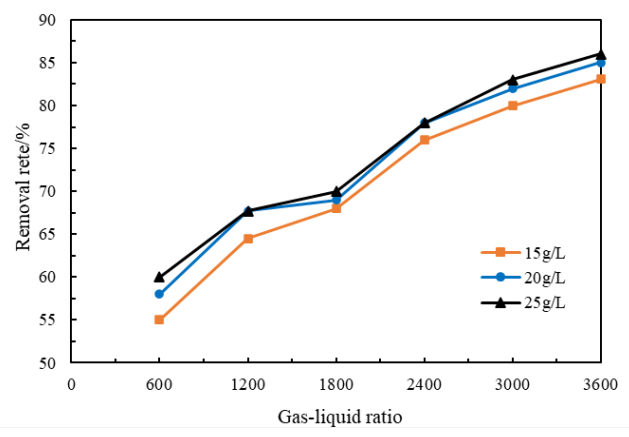

Fig. 9. Effects of second-stage stripping on ammonia nitrogen in effluent

\subsection{Effect of second-stage stripping on COD in effluent}

As shown in Table 2, when the dosage of $\mathrm{CaO}$ added in the effluent of the first-stage tower is $15 \mathrm{~g} / \mathrm{L}, 20 \mathrm{~g} / \mathrm{L}$, and $25 \mathrm{~g} / \mathrm{L}$, the COD of the solution drops from 5821, 6250, $4317 \mathrm{mg} / \mathrm{L}$ to $3103,2465,2763 \mathrm{mg}$, respectively $/ \mathrm{L}$, the average removal rate is $27 \%, 42 \%, 36 \%$, This may be because the addition of $\mathrm{CaO}$ leads to an increase in the electrolyte concentration in the membrane concentrate, a decrease in the thickness of the colloidal electric double layer, aggregation and precipitation between particles, and the formation of $\mathrm{CaCO}_{3}$ and $\mathrm{Mg}(\mathrm{OH})_{2}$ precipitation, which has a coagulation effect[15-18]. Then use a twostage tower for stripping under the condition of a gasliquid ratio of 3600 .The $\mathrm{COD}$ of the membrane concentrate after adding alkaline agent increased to 3612 , $2720,3349 \mathrm{mg} / \mathrm{L}$, This may be because $\mathrm{NH}_{4}{ }^{+}$and $\mathrm{OH}^{-}$in the membrane concentrate continuously combine to form NH3 during the ammonia stripping process. The electrolyte concentration in the solution decreases, the thickness of the colloidal double layer increases, the cohesion between the colloids weakens, and the coagulation effect weakens [17-18].

Table 2. Variation of $\mathrm{COD}$ after adding $\mathrm{CaO}$ and ammonia stripping

\begin{tabular}{|c|c|c|c|c|c|}
\hline \multirow{2}{*}{$\begin{array}{l}\text { Dosage } \\
\text { of } \\
\text { calcium } \\
\text { oxide } \\
\left(\mathrm{g} \cdot \mathrm{L}^{-1}\right)\end{array}$} & \multirow{2}{*}{$\begin{array}{l}\text { COD of } \\
\text { the } \\
\text { effluent } \\
/(\mathrm{mg} \\
\left.\cdot \mathrm{L}^{-1}\right)\end{array}$} & \multicolumn{2}{|c|}{$\begin{array}{l}\text { COD after adding } \\
\text { Calcium Oxide }\end{array}$} & \multicolumn{2}{|c|}{ COD after stripping } \\
\hline & & $\begin{array}{c}\text { Content/ } \\
(\mathrm{mg} \cdot \\
\left.\mathrm{L}^{-1}\right)\end{array}$ & $\begin{array}{l}\text { Removal } \\
\text { rate } / \%\end{array}$ & $\begin{array}{l}\text { Content/ } \\
(\mathrm{mg} \cdot \\
\left.\mathrm{L}^{-1}\right)\end{array}$ & $\begin{array}{l}\text { Removal } \\
\text { rate } / \%\end{array}$ \\
\hline 15 & \multirow{3}{*}{4250} & 2635 & 38 & 3358 & 21 \\
\hline 20 & & 2677 & 37 & 3060 & 28 \\
\hline 25 & & 2720 & 36 & 3315 & 22 \\
\hline
\end{tabular}

\section{Conclusion}

(1) The higher the stripping temperature of the firststage tower was, the greater the increase in the $\mathrm{pH}$ value of the anaerobic digestion solution was in the same time, the greater the decrease in alkalinity was, and the better the stripping effect. When the gas-liquid ratio is set to 2400 and the experimental temperature is $20^{\circ} \mathrm{C}, 30^{\circ} \mathrm{C}$, and $40^{\circ} \mathrm{C}$, the $\mathrm{pH}$ of the solution rises from the initial 7.8 to $8.32,8.49$, and 8.55 , respectively, and the removal rate of ammonia nitrogen is $1.2 \% .4 .7 \%, 7.7 \%$. When the gas-liquid ratio is 3600 and the experimental temperature is $20^{\circ} \mathrm{C}, 30^{\circ} \mathrm{C}$, and $40^{\circ} \mathrm{C}$, the $\mathrm{pH}$ of the solution rises from the initial 7.8 to $8.4,8.54,8.63$, respectively, and the removal rate of ammonia nitrogen is $2.2 \%$ and $5.2 \%$, $11.8 \%$.

(2) Through the closed loop cycle, $\mathrm{CO}_{2}$ in the air can be effectively removed, and the partial pressure difference between the free $\mathrm{CO}_{2}$ in the liquid phase and the $\mathrm{CO}_{2}$ in the gas phase can be increased. When the gasliquid ratio is 3600 and the stripping temperature is $40^{\circ} \mathrm{C}$, the $\mathrm{pH}$ of the biogas slurry after the closed cycle treatment reaches 8.75 , and the alkalinity is also reduced from the initial 8150 to $6615 \mathrm{mg} / \mathrm{L}$.

(3) When $\mathrm{CaO}$ is added to the effluent of the firststage tower, the COD of the concentrate will decrease due to coagulation and the mechanism of compressing the electric double layer, and the $\mathrm{PH}$ value will also increase.After the second-stage ammonia stripping, COD 
increases. Under the condition of gas-liquid ratio of 3600 , the whole system is running, and when $\mathrm{CaO}$ is added at $25 \mathrm{~g} / \mathrm{L}$, the COD removal rate is $22.4 \%$, and the ammonia nitrogen removal rate is up to $86 \%$.

\section{References}

1. Yuan Chuang, Gong Weicheng, Kuang Hongye. Research progress of biogas liquid membrane con centration technology[J]. Agriculture and Technol ogy, 2017(21):166-169

2. Lu Jia, Liu Wei, Wang Xin, et al. Experimental s tudy on ultrafiltration membrane concentration tre atment of biogas slurry[J]. Applied Energy Techn ology, 2016, 000(008): 49-53

3. Song Chengfang, Shan Shengdao, Zhang Miaoxia $\mathrm{n}$, et al. Experimental study on membrane filtratio $\mathrm{n}$ and concentration of biogas slurry from livestoc $\mathrm{k}$ and poultry breeding[J]. China Water \& Waste water, 2011, 027(003): 84-86

4. Laureni M, Palatsi J, Llovera M, et al. Influence o f pig slurry characteristics on ammonia stripping e fficiencies and quality ofthe recovered ammoniu $\mathrm{m}$ - sulfate solution[J]. Journal of Chemical Tech nology \& Biotechnology, 2013, 88(9):1654-1662

5. Xu Guoqiang, Zeng Guangming, Yin Zhiwei, etc. Status and development of ammonia nitrogen wa stewater treatment technology [J]. Hunan Nonferr ous Metals, 2002, 18(2): 29-30

6. Vijay K. Minocha,A.V.S Prabhakar Rao. Ammon ia removal and recovery from urea fertilizer plant waste[J]. Environmental Technology,1988,9(7)

7. Wang Wenbin, Dong You, Liu Shiting. Research on the removal of ammonia nitrogen in landfill le achate by blowing off method[J]. Environmental Pollution Control Technology and Equipment, 20 04, 6(5): 51-53

8. K.W. Pi,Z. Li,D.J. Wan,L.X. Gao.Pretreatment of municipal landfill leachate by a combine d process $[\mathrm{J}]$. Process Safety and Environmental Protection . 2009, 87 (3): 191-196

9. Li Ruihua, Wei Chaohai, Wu Chaofei, et al. Cond ition test and engineering application of pretreatm ent of ammonia nitrogen in coking wastewater by stripping method $[\mathrm{J}]$. Environmental Engineeri ng, 2007, 25(3): 38-44

10. Gustin S, Marinsek-Logar R. Effect of $\mathrm{pH}$, tempe rature and air flow rate on the continuous ammoni a stripping of the anaerobic digestion effluent[J]. Process Safety \& Environmental Protection, 2011, 89(1): $61-66$

11. Acidity, alkalinity and $\mathrm{pH}$ value $[\mathrm{J}]$. Environment al Science Series, 1988(02): 11-22

12. YONG H K, YEOM S H, RYU J Y, et al. Develo pment of a novel UASB/CO2-stripper system for the removal of calcium ion in paper wastewater[J]. Process Biochemistry,2004,39(11):1393-1399

13. Zhang $\mathrm{Xu}$, Wang Baozhen, Zhu Hong. The $\mathrm{pH}$ an d buffering capacity of anaerobic digestion syste m[J]. China Environmental Science, 1997(06): 13 $-17$

14. Li Xiaoping, Wei Quanyuan, Jin Mingjun, Hu Jin g, Xu Pan, Dong Renjie. CO_2 stripping to increa se the $\mathrm{pH}$ value of anaerobic fermentation broth [J]. China Biogas, 2010, 28(03): 3-7

15. Quan X, Ye C, Xiong Y, et al. Simultaneous re moval of ammonia, $P$ and COD from anaerobicall $\mathrm{y}$ digested piggery wastewater using an integrated process of chemical precipitation and air strippin $\mathrm{g}[\mathrm{J}]$. Journal of Hazardous Materials, 2010, 178(1 $-3): 326-332$

16. Chen Yingmin, Sun Xinli, Wu Jingran. The influe nce of phosphorus-based scale inhibitors on the $\mathrm{c}$ oagulation effect of the reuse of circulating water and sewage and the measures [J]. Thermal Power Generation, 2010, 039(001): 95-99

17. Zhang Huan, Zhao Yunxin. Research on the remo val of cadmium from water by hydroxy-magnesiu m-aluminum complexes[J]. Northern Environmen t, 2013, 000(012): 58-61

18. Zou Mengyuan, Dong Hongmin, Zhu Zhiping, et al. The effect of inert fillers on the removal of am monia from biogas slurry in pig farms[J]. Transac tions of the Chinese Society of Agricultural Engin eering, 2018, 34(23):194-200 